\title{
KEDAULATAN WILAYAH UDARA DI ATAS ALUR LAUT KEPULAUAN INDONESIA (ALKI)
}

(Sovereignty of Airspace Above the Indonesian Archipelago Sea Groove (ALKI))

\author{
Wulan Pri Handini \\ Magister Ilmu Hukum, Fakultas Hukum Universitas Indonesia \\ Jl. Salemba Raya No.4 Jakarta Pusat \\ email:wulanphandini@gmail.com \\ Danang Risdiarto \\ Badan Pembinaan Hukum Nasional \\ Jl. Mayjen Sutoyo No.10 Cililitan Jakarta Timur \\ email: risdiarto@gmail.com
}

Naskah diterima: 13 Juni 2019; revisi: 22 Juli 2019; disetujui: 2 Agustus 2019

\begin{abstract}
Abstrak
Sesuai dengan Konvensi PBB tentang Hukum Laut (UNCLOS) 1982 Indonesia memiliki 3 (tiga) ALKI (Alur Laut Kepulauan Indonesia). UNCLOS Tahun 1982 menegaskan bahwa negara kepulauan seperti Indonesia dapat menentukan ALKI dan rute penerbangan di atasnya. Persoalan yang terjadi adalah dalam ALKI tersebut ternyata oleh rezim hukum laut diberikan hak terbang melintas "bebas" bagi pesawat terbang yang melintasi wilayah udara tersebut. Sedangkan menurut hukum udara internasional tidak mengenal adanya jalur lintas bebas karena dalam Konvensi Chicago kedaulatan negara di ruang udara bersifat komplit dan eksklusif. Penelitian ini akan membahas mengenai permasalahan yang terjadi akibat perbedaan antara rezim hukum laut dengan hukum udara yang terjadi di atas ALKI. Dari hasil penelitian ini dapat disimpulkan bahwa dalam PP No. 4 Tahun 2018 tentang Pamwilud secara khusus telah mengatur mengenai unsur-unsur pelanggaran termasuk sanksi serta siapa yang mempunyai kewenangan untuk melaksanakan penegakan hukum jika terjadi pelanggaran oleh pesawat udara tidak berizin di ruang udara di atas ALKI. Untuk mendukung pengamanan di ruang udara di atas ALKI perlu menetapkan Zona Identifikasi Pertahanan Udara (ADIZ) melalui Keputusan Presiden (Keppres).
\end{abstract}

Kata Kunci: ALKI, ruang udara, pelanggaran, kedaulatan

\begin{abstract}
In accordance with the United Nations Convention on the Law of the Sea (UNCLOS) 1982 Indonesia has 3 (three) ALKIS (Indonesian Archipelago Sea Grooves). UNCLOS in 1982 emphasized that an archipelagic country such as Indonesia could determine the ALKI and flight routes on it. The problem that occurs is in the ALKI it turns out that by the legal regime the sea is given the right to fly "free" for aircraft that cross the airspace. Meanwhile, according to international air law, there is no free crossing because in the Chicago Convention the sovereignty of the state in the air space is complete and exclusive. This study will discuss the problems that occur due to differences between the sea law regime and the air laws that occur above ALKI. From the results of this study it can be concluded that in PP No.4 of 2018 concerning Pamwilud specifically regulates the elements of violations including sanctions and who has the authority to carry out law enforcement in the event of violations by unauthorized aircraft in the airspace above ALKI. To support security in the airspace above ALKI needs to establish an Air Defense Identification Zone (ADIZ) through a Presidential Decree (Keppres).
\end{abstract}

Keywords: ALKI, air space, violation, sovereignty 


\section{A. Pendahuluan}

Dua pertiga dari wilayah Indonesia merupakan laut, yang letak geografisnya sangat strategis dimana Indonesia adalah negara kepulauan terbesar di dunia, juga di dalamnya mengandung potensi sumber daya alam yang amat besar. Indonesia terdiri dari 17.499 pulau dan $80.791 \mathrm{~km}$ garis pantai, ${ }^{1}$ dihuni oleh 1.340 suku bangsa dengan hampir seribu bahasa daerah. ${ }^{2}$

Dalam hitungan matematis, wilayah Indonesia meliputi dua pertiga lautan dan sepertiga daratan. Di atas lautan dan daratan ada wilayah udara yang mencakup tiga pertiga dari keseluruhan wilayah. ${ }^{3}$ Itulah wilayah Negara Kesatuan Republik Indonesia (NKRI) yang harus dijaga kedaulatan, kehormatan dan keamanan nasionalnya. Inilah salah satu penyebab kompleksnya menjaga kedaulatan NKRI. Wilayah kepulauan Nusantara inilah yang pada tahun 1957 dideklarasikan sebagai wilayah kedaulatan Indonesia melalui Deklarasi Juanda. Sepuluh tahun kemudian yaitu tahun 1967, deklarasi itu disebut Wawasan Nusantara sebagai konsep geopolitik bangsa Indonesia yang sekaligus melandasi wawasan kebangsaannya.

Indonesia sebagai negara kepulauan yang berada di antara Benua Asia dan Australia serta Samudra Hindia dan Pasifik, di satu sisi mempunyai posisi strategis sekaligus tantangan besar dalam mengamankannya.
Pemerintah Indonesia dalam menjalankan tugas dan fungsi kedaulatannya di Perairan Indonesia yang meliputi Perairan Pedalaman, Perairan Kepulauan, dan Laut Teritorial harus mengakomodasi kepentingan internasional khususnya lintas (pelayaran dan penerbangan) melalui perairan kepulauan dan laut teritorial Indonesia. Hal ini sesuai dengan ketentuan Konvensi Hukum Laut 1982 yang mewajibkan negara pantai maupun negara kepulauan dalam melaksanakan kedaulatannya harus didasarkan kepada ketentuan Konvensi. ${ }^{4}$

Sesuai dengan Konvensi PBB tentang Hukum Laut (UNCLOS) 1982,5 Indonesia memiliki tiga ALKI (Alur Laut Kepulauan Indonesia) dan beberapa choke points yang strategis bagi kepentingan global, seperti di Selat Sunda, Selat Lombok, dan Selat Makassar. Pengamanan ALKI serta seluruh choke points tersebut merupakan agenda strategis bagi kepentingan nasional Indonesia serta masyarakat internasional.

Persoalan ALKI terkait erat dengan kedaulatan Indonesia sebagai suatu bangsa. Kedaulatan merupakan salah satu syarat berdirinya suatu negara. Salah satu unsur dari negara ialah pemerintah yang berkedaulatan. Pemerintah dalam suatu negara harus memiliki kewibawaan (authority) yang tertinggi (supreme) dan tidak terbatas. ${ }^{6}$

Sebuah negara yang memiliki kedaulatan bertujuan untuk menjalankan pemerintahan 
dan membatasi dari ancaman negara lain. Kedaulatan bersifat mengikat masyarakat dan elemen negara untuk menjunjung tinggi harkat dan martabat seluruh tumpah darah yang dilindungi. Dalam hal ini kedaulatan negara berfungsi untuk menjaga sebuah negara agar bisa berjalan sesuai dengan aturan undangundang dan menentukan siapa kekuasaan tertinggi dalam sebuah negara. Kedaulatan negara bersifat mutlak dan patut untuk dipertahankan oleh segenap elemen bangsa tersebut. Kedaulatan sebuah negara meliputi tanah, air, udara, dan segenap potensi alam yang terkandung di dalamnya.

Wilayah suatu negara terdiri dari tanah, air, dan udara, oleh karena itu negara adalah suatu kesatuan politis (one political unit) sehingga tidak dapat dipisah-pisahkan. Sebagai negara yang merdeka dan berdaulat tentunya pantas kalau Indonesia harus sanggup dan mampu menjaga integritas dan keamanan negaranya dan jika perlu menggunakan kekerasan senjata. Indonesia mempunyai kedaulatan penuh serta eksklusif terhadap ruang udara di atas wilayah daratan dan di atas wilayah perairan yang menurut undang-undang merupakan perairan teritorial Indonesia. ${ }^{7}$

Mochtar Kusumaatmadja, dalam menghadapi penolakan dunia internasional terhadap Deklarasi Djuanda pernah berkata "Setiap negara berdaulat pada dasarnya memiliki kedaulatan penuh untuk melakukan tindakan yang dianggap perlu dalam rangka pengamanan yurisdiksi lautnya". ${ }^{8}$ Indonesia sebagai negara kepulauan terbesar di dunia, harus dapat menjawab tantangan besar dalam mengamankan wilayah lautnya, termasuk potensi dan sumber daya alam yang ada di dalamnya demi kedaulatan dan kesejahteraan rakyatnya.

Wilayah kedaulatan Indonesia tidak hanya berada di daratan maupun lautannya saja, namun mencakup pula ruang udara di atas daratan maupun lautan. Berdasarkan Pasal 1 Konvensi Chicago tahun 1944, secara tegas menyatakan bahwa semua negara mempunyai suatu kedaulatan yang utuh dan komplit/ penuh (complete and exclusive sovereignity) atas ruang udara atas wilayah kedaulatannya. Istilah complete and exclusive sovereignty mengandung arti bahwa kedaulatan di udara adalah penuh dan eksklusif. Kedaulatan yang penuh adalah kedaulatan yang mutlak, sedangkan kedaulatan yang eksklusif adalah hak negara untuk memanfaatkan dan mengatur ruang udaranya. ${ }^{9}$

Penggunaan istilah yang ada di Konvensi Chicago 1944 dituangkan dalam Pasal 5 Undang-Undang Nomor 1 Tahun 2009 tentang Penerbangan yang berbunyi: “Negara Kesatuan Republik Indonesia berdaulat penuh dan eksklusif atas wilayah udara Republik Indonesia." Oleh sebab itu ada irisan antara pengaturan ruang udara yang ada di Konvensi Chicago tahun 1944 dengan peraturan hukum yang diakui secara resmi di Indonesia. Namun ironisnya meskipun telah diatur dengan sebuah Konvensi internasional masih kerap terjadi pelanggaran wilayah udara oleh pesawat udara negara lain.

Selain itu rezim hukum udara tidak mengenal adanya lintas damai. Pesawat

Priyatna Abdurrasyid, Kedaulatan Negara di Ruang Udara (Jakarta: Fikahati Aneska, 2003), hlm. 161-162.

8 Mochtar Kusumaatmadja, Konsepsi (Negara) Kepulauan Dalam Hukum Laut dan Wawasan Nusantara (Jakarta: Badan Pembinaan Hukum Nasional), hlm.3.

9 Kresno Buntoro, Alur Laut Kepulauan Indonesia (ALKI). Prospek dan Kendala. (Jakarta: Seskoal, 2012), hlm xiii. 
udara asing baik berjadwal maupun tidak berjadwal tetap memerlukan izin untuk memasuki wilayah udara negara lain. Rute penerbangan khusus untuk pesawat udara sipil ditentukan oleh Organisasi Penerbangan Sipil Internasional -International Civil Aviation Organization (ICAO), sedangkan pesawat udara milik negara asing yang akan melintas harus mendapatkan izin dan persetujuan rute penerbangan yang akan dilewati.

Berkaitan dengan ruang udara di atas ALKI, UNCLOS Tahun 1982 Pasal 53 yang telah diratifikasi dengan Undang-Undang Nomor 17 Tahun 1985 Tentang Pengesahan United Nations Convention on The Law of The Sea, menegaskan bahwa negara kepulauan seperti Indonesia dapat menentukan ALKI dan rute penerbangan di atasnya. Dari ketentuan konvensi tersebut, ruang udara di atas ALKI dibagi-bagi dalam ALKI I, ALKI II dan ALKI III. Sementara itu, negara maju seperti Amerika Serikat (AS) belum meratifikasi Konvensi ini, sehingga apabila kapal atau pesawat udara AS yang melintas ruang udara di atas ALKI masih berpedoman kepada aturan-aturan yang lama (Traditional Route for Navigation). Hal ini sering menimbulkan permasalahan dimana berdasarkan aturan lama tersebut pesawat-pesawat AS yang melintas di atas rute tradisional mereka anggap sah dengan alasan bahwa AS belum meratifikasi UNCLOS Tahun $1982 .{ }^{10}$

Alasan AS belum meratifikasi UNCLOS 1982 adalah karena pasal 11 mengenai "Otoritas Dasar Laut Internasional." Karena aturan itu telah melanggar prinsip ekonomi bebas dan pembangunan, jadi pemerintah AS tidak mau menandatanganinya. Tapi pasal lain di luar pasal 11, AS mengumumkan dapat mentaatinya.

Pada dasarnya, pemerintah AS termasuk kalangan akademisnya bersikap menentang konvensi ini, adalah karena khawatir sumber kelautan akan dianggap sebagai "kekayaan bersama" manusia, ini sama saja dengan mengusung "komunis" ala paham sosialisme di seluruh dunia. Ini sangat bertentangan dengan kebijakan ekonomi bebas dan hak kekayaan pribadi yang selama ini dianut oleh AS. Pada 1994 Presiden Clinton setuju untuk ikut dalam konvensi, dan mengajukannya untuk diloloskan di Dewan Kongres. Tapi konvensi itu sampai sekarang belum mendapat persetujuan dari Dewan Kongres. Kemudian Presiden Bush Jr. juga sempat mengajukan hal yang sama, tapi tetap dihadang oleh para anggota Dewan Kongres yang berhaluan keras. Pada Mei 2014, Presiden Obama kembali menghimbau Dewan Kongres agar menyetujui UNCLOS. Obama berkata, "Kita tidak bisa membuat pengecualian bagi kita sendiri sementara semua negara lain diminta mentaati peraturan itu." 11

10 Soegiyono, “Kajian Kedaulatan NegaraDiRuangUdara Terhadap Alur Laut Kepulauan Indonesia (ALKI)," Berita Dirgantara Vol.12 No.2 Juni 2011: 76-82.

11 http://www.erabaru.net/2016/08/05/mengapa-amerika-tidak-mengikuti-konvensi-hukum-zona-lautinternasional-3/ (diakses 22 Juli 2019) 


\section{Peta Alur Laut Kepulauan Indonesia (ALKI) Berdasarkan PP No. 37 / 2002}

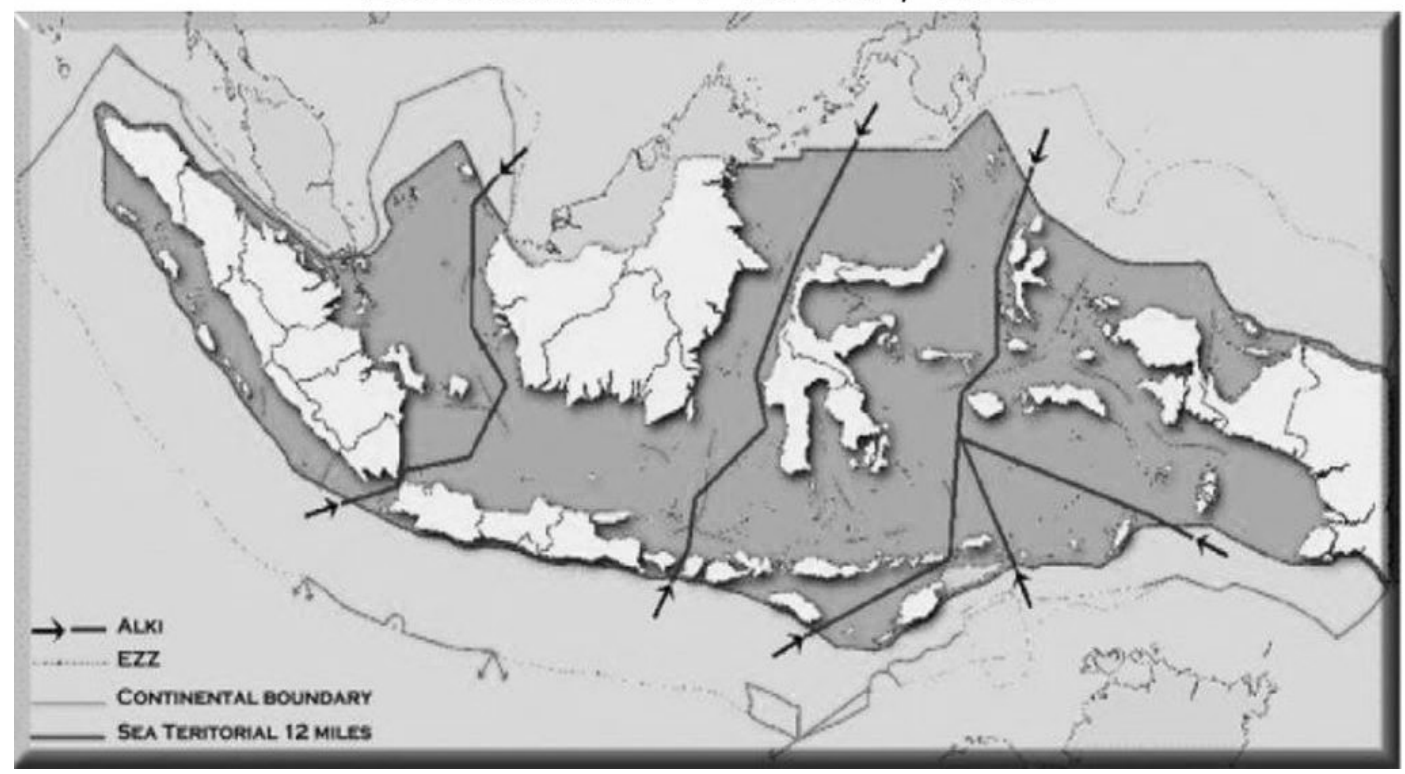

Gambar 1. Alur Laut Kepulauan Indonesia (ALKI)

Persoalan lainnya adalah dalam alur ALKI tersebut ternyata oleh rezim hukum laut diberikan hak terbang melintas "bebas" bagi pesawat terbang yang merupakan bagian dari gugus armada laut tersebut. Mengenai ini, maka terjadilah perbedaan persepsi tentang penerapan hukum udara internasional yang tidak mengenal jalur lintas bebas, karena dalam Konvensi Chicago kedaulatan negara adalah komplit dan eksklusif. Lebih dari itu, lintas terbang di atas ALKI, ternyata juga telah digunakan bagi pesawat-pesawat terbang yang bukan merupakan bagian dari gugus armada laut yang melintas, akan tetapi digunakan sebagaimana layaknya "airways". Perbedaan persepsi inilah yang menjadi pekerjaan rumah untuk dapat segera menyelesaikan multi persepsi dari UNCLOS
Tahun 1982, yang di satu sisi memberikan pengakuan secara internasional terhadap eksistensi negara kepulauan namun di sisi lainnya memunculkan beberapa masalah dalam jalur lintas udara. ${ }^{12}$

Maraknya pelanggaran udara di wilayah ALKI ini juga dinyatakan oleh pihak TNI Angkatan Udara (TNI AU) yang menyatakan kebanyakan pelanggaran terjadi pada ALKI III. Banyaknya pelanggaran di wilayah itu lantaran banyaknya pesawat asing yang melintas. ALKI III terbilang digemari karena menghubungkan wilayah utara dan selatan. ${ }^{13}$

Selain itu salah satu satu wilayah udara yang kerap terjadi pelanggaran oleh pesawat asing adalah di Natuna. Rata-rata pesawat tujuan Malaysia dan Singapura memotong jalur kawasan itu. Daerah tersebut sebagai

\footnotetext{
12 Chappy Hakim, Menjaga Kedaulatan Negara di Udara http://www.chappyhakim.com/menjaga-kedaulatan-negara-diudara/ (diakses 29 Mei 2019).

13 TNI AU dan AirNav Klaim Pelanggaran di Ruang Udara Menurun https://www.wartaekonomi.co.id/ read167096/tni-au-dan-airnav-klaim-pelanggaran-di-ruang-udara-menurun.html (diakses 12 Juni 2019 ).
} 
'jalan potong' penerbangan dari Jepang dan Filipina yang termasuk jalur ALKI II.

Salahsatupenyebab maraknya pelanggaran wilayah udara Indonesia adalah lemahnya regulasi yang mengatur mengenai kedaulatan wilayah udara. Dengan pertimbangan untuk melaksanakan ketentuan Pasal 9 UndangUndang (UU) Nomor 1 Tahun 2009 tentang Penerbangan, pada 13 Februari 2018, Presiden Joko Widodo telah menandatangani Peraturan Pemerintah Nomor 4 Tahun 2018 tentang Pengamanan Wilayah Udara Republik Indonesia (PP No. 4 Tahun 2018 tentang Pamwilud).

Dalam PP ini ditegaskan, dalam rangka penyelenggaraan kedaulatan negara atas Wilayah Udara Negara Kesatuan Republik Indonesia (NKRI), Pemerintah melaksanakan wewenang dan tanggung jawab pengaturan ruang udara untuk kepentingan penerbangan, perekonomian nasional, pertahanan dan keamanan negara, sosial budaya, serta lingkungan udara.

Pengesahan peraturan pemerintah ini tentunya diharapkan dapat mengatasi maraknya pelanggaran wilayah udara khususnya yang terjadi di atas ALKI karena selama ini terjadi perbedaan persepsi antara rezim hukum laut dan hukum udara mengenai hak lintas damai bagi pesawat udara baik sipil maupun militer yang melintasi ALKI.

Berdasarkan latar belakang diatas maka penelitian ini akan membahas mengenai permasalahan yang terjadi akibat perbedaan antara rezim hukum laut dengan hukum udara yang terjadi di atas ALKI dan bagaimana solusinya dalam peraturan perundangundangan di Indonesia.

\section{B. Metode Penelitian}

Penelitian ini dilakukan dengan metode yuridis normatif yang dilakukan melalui studi pustaka yang menelaah (terutama) data sekunder yaitu peraturan perundangundangan, hasil penelitian, hasil pengkajian dan referensi lainnya ${ }^{14}$. Metode ini juga digunakan untuk mengungkapkan berbagai perangkat hukum yang terkait pengaturan terhadap ruang udara Indonesia dan ALKI.

Pengumpulan data dilakukan dengan meneliti data mengenai peraturan perundangundangan yang mengatur tentang ketentuan dan tata cara prosedur penerbangan di atas ALKI dan peraturan lain di bawahnya yang berkaitan dengan hal tersebut.

Sedangkan untuk teknik pengumpulan data bagi kegiatan ini dilakukan melalui penelitian kepustakaan ${ }^{15}$. Penelitian ini dimaksudkan untuk mencari landasan teoritis (filosofis, yuridis, ekonomi) juga berbagai informasi mengenai pelaksanaan penerbangan di wilayah udara ALKI. Bahan hukum sekunder yang digunakan yaitu buku-buku, karya ilmiah dan hasil penelitian yang berkaitan dengan objek yang dibahas. Pengumpulan data dilengkapi pula dengan artikel hukum dari internet ataupun artikel ilmiah lainnya yang dapat mendukung kelengkapan data dalam penelitian ini. Data dari hasil penelitian ini kemudian dianalisa secara kualitatif, artinya data kepustakaan dianalisa secara mendalam, holistik, dan

14 Lampiran I Undang-Undang Republik Indonesia Nomor 12 Tahun 2011 tentang Pembentukan PeraturanPerundang-Undangan.

15 Soerjono Soekanto dan Sri Mamudji, Penelitian Hukum Normatif. Suatu Tinjauan Singkat, (Jakarta: Raja Grafindo Persada, 2004), hlm. 29-33. 
komprehensif. Penggunaan metode analisa kualitatif didasarkan pada pertimbangan data yang dianalisa beragam, memiliki perbedaan antara satu dengan lainnya, serta tidak mudah untuk dikuantitatifkan.

\section{Pembahasan}

\section{Kedaulatan Negara di Ruang Udara}

Landasan hukum bagi kepulauan Indonesia sebagai satu kesatuan wilayah yang terdiri dari daratan, lautan dan udara di atasnya telah diperjuangkan melalui forum internasional sejak diumumkannya Deklarasi Juanda pada tanggal 13 Desember 1957. Ide serta konsep yang melatarbelakangi Deklarasi tersebut pada tahun 1967 dicanangkan sebagai konsep Wawasan Nusantara. Selanjutnya oleh para wakil rakyat dan utusan golongan serta daerah dalam Majelis Permusyawaratan Rakyat (MPR), pemikiran tersebut ditetapkan dalam Garis Besar Haluan Negara (GBHN) 1973-1978.

Akhirnya setelah melalui perjuangan dan diplomasi yang panjang serta melelahkan konsensus tersebut diakui oleh dunia melalui Perserikatan Bangsa-Bangsa. Konsep tersebut kemudian menjadi sebuah prinsip hukum internasional baru yang dicantumkan dalam United Nations Conventions on the Law of the Sea (UNCLOS) 1982. Konsep ini kemudian lebih dikenal dengan Prinsip Negara Kepulauan (Archipelagic State Principle). Sesuai ketentuan dalam UNCLOS 1982 mengenai Negara Kepulauan, maka kondisi sosial, politik, geografi serta ekonomi, Indonesia yang berciri khas negara kepulauan memenuhi syarat guna ditetapkan menjadi Negara Kepulauan dengan berciri maritim. ${ }^{16}$

Konsekuensi dengan ditetapkannya Indonesia sebagai Negara Kepulauan melalui UNCLOS 1982 ini adalah Indonesia harus mampu menjaga kedaulatannya baik di darat, laut maupun udara. Salah satu pakar hukum udara dan ruang angkasa Prof. Dr. Priyatna Abdurrasyid dalam bukunya menyatakan bahwa Kepulauan Indonesia merupakan suatu unit kesatuan Nusantara yang terdiri dari dimensi daratan, dimensi lautan yang jelas batas-batasnya. Dimensi ketiga, yakni wilayah udara perlu mendapat penelitian dan pembahasan selanjutnya.

Seperti telah dikemukakan terdahulu, Pasal 1 Konvensi Chicago 1944 menyatakan bahwa negara-negara berdaulat utuh dan eksklusif terhadap ruang udara (airspace) di atas wilayahnya. Tetapi kemudian Konvensi tersebut tidak pernah menjelaskan apa dan pada jarak berapa batas-batas wilayah udara di atas wilayah negara. Hal ini yang kemudian menimbulkan banyak sengketa dan perselisihan terkait batas kedaulatan wilayah suatu negara. ${ }^{17}$

Dalam Pasal 1 Konvensi Chicago hak lintas juga sama sekali ditiadakan, walaupun hak itu dibenarkan bagi pesawat-pesawat udara sipil yang tidak berjadwal asal saja memenuhi syarat-syarat yang ditetapkan oleh negaranegara yang dilaluinya. Pasal 1 mengatakan bahwa kedaulatan negara di ruang udara yang ada atasnya bersifat penuh dan mutlak atau complete and exclusive. Apakah ini berarti ke angkasa tanpa batas? Secara logis hal ini tidak memungkinkan karena kedaulatan itu hanya

16 Wahyono S.K . Indonesia Negara Maritim, (Jakarta: Teraju, 2009), hlm. 4-5.

17 Priyatna Abdurrasyid, Op.cit., hlm. 17. 
di atmosfir saja, sedang gerak dan bentuk tata surya kita tidak memungkinkan untuk melakukan hal tersebut.

Sengketa lain juga disebabkan Konvensi yang berlaku tidak pernah menjelaskan apa yang dimaksud dengan "ruang udara" (airspace), walaupun dapat dilakukan penafsiran jarak ketinggian dengan menghubungkannya pada istilah pesawat udara yang bergerak di atmosfir karena mendapat gaya angkat dari reaksi-reaksi udara. Selama ini jarak "ruang udara" ini selalu ditafsirkan oleh negara-negara sesuai dengan kepentingannya masing-masing. ${ }^{18}$

Secara pokok ada dua teori utama yang ada dalam menafsirkan batas vertikal dari ruang udara/wilayah udara, yaitu teori spatialist yang menghendaki agar batas-batas kedaulatan ditentukan dengan membagi secara tegas antara airspace (ruang udara) dan outer space (ruang angkasa) dan teori fungsional yang menentang pembagian ruang udara dengan antariksa secara spatial (dikotak-kotakkan menurut ruang). Teori fungsional lebih lanjut berpandangan bahwa ruang udara dan ruang angkasa adalah satu kesinambungan yang tidak terpisahkan. ${ }^{19}$

Konsep kedaulatan udara mengacu pada hukum udara internasional yang menjelaskan bahwa pesawat udara negara termasuk pesawat militer milik pemerintah tidak mempunyai hak lintas terbang atau mendarat di wilayah suatu negara tanpa adanya pemberian hak khusus dari negara yang dilaluinya. Negara tersebut juga harus memberikan perlakuan yang sama dan tidak diskriminatif terhadap negara-negara lain yang menggunakan ruang udaranya. Hal ini untuk menciptakan penerbangan internasional yang lebih aman dan lebih lancar. ${ }^{20}$ (Yanyan Mochamad Yani, 2017: 16-18):

\section{Pelanggaran Wilayah Udara di Atas ALKI}

Pada tanggal 3 Juli 2003, radar TNI AU menangkap pergerakan lima pesawat F-18 Hornet US Navy di wilayah udara Indonesia. Kelima pesawat tersebut kedapatan melakukan formasi tempur. Namun belum sempat diidentifikasi tiba-tiba kelima pesawat tersebut menghilang dari radar. Akibat menghilang dari radar maka Kosek Hanudnas II tidak melaporkan kejadian tersebut ke pusat. Secara tiba-tiba, sekitar tiga jam kemudian keberadaan kelima pesawat tersebut kembali terdeteksiradar. Penerbangan pesawat tempur AS tersebut bahkan membuat dua maskapai yaitu Bouraq Indonesia dan Mandala Airlines protes karena mengganggu rute penerbangan internasional. Apalagi penerbangan tersebut tidak dilaporkan ke ATC terdekat sehingga black flight pesawat tempur tersebut sangat mencurigakan.

TNI AU segera mengudarakan dua pesawat tempur F-16/Fighting Falcon dari Lanud Iswahyudi Madiun untuk melakukan identifikasi visual dan diminta untuk menghindari konfrontasi dengan pesawat Angkatan Laut AS atau US Navy. Tidak lama setelah lepas landas, kedua pesawat TNI AU tersebut segera dibidik dan dikunci (lock on) oleh F-18/Hornet tersebut. Tidak

Priyatna Abdurrasyid, Op.cit., hlm. 129-130.

19 T. Bambang Widarto, Tinjauan Hukum Udara Sebagai Pengantar. Dalam Perspektif Hukum Internasional dan Nasional, (Jakarta: Sekolah Tinggi Hukum Militer, 2015), hlm. 36-50.

20 Yanyan Mochammad Yani, Ian Montratama dan Ikradhi Putera. Langit Indonesia Milik Siapa? Makna Strategis Wilayah Pengendalian Udara (FIR) Indonesia-Singapura, (Jakarta: Elex Media Komputindo, 2017), hlm. 16-18. 
hanya dibidik, pesawat Hornet tersebut juga melancarkanjamming (mematikan komunikasi radio) yang kemudian berhasil diantisipasi oleh penerbang TNI AU. Berbagai manuver dilakukan penerbang TNI AU agar terlepas dari penguncian. Mulai manuver penghindar seperti hard break ke kiri dan ke kanan, atau zig-zagging yang bisa menyebabkan awaknya terkena efek grafitasi hingga 9 G-Force, atau sembilan kali gravitasi tarikan bumi. Setelah melakukan berbagai manuver, akhirnya penerbang TNI AU memberikan isyarat berupa rocking the wing (menggerakgerakan sayap ke atas dan ke bawah), untuk menunjukkan mereka bukan ancaman bagi F/A 18 Hornet milik AS. Sekitar satu menit kemudian, kedua F-16 berhasil berkomunikasi dengan kedua Hornet yang mencegat mereka. Dari komunikasi singkat itu akhirnya diketahui bahwa mereka mengklaim sedang terbang di wilayah perairan internasional. Masih dalam nuansa tegang, penerbang F-16 kembali melihat kapal perusak US Navy, dan langsung melaporkannya. Kontak ini terjadi pada ketinggian 15.000 kaki dan berhasil menjauh dari bidikan lawan.

Ketegangan berlanjut ketika radar kembali menemukan manuver pesawat asing pada jarak 40 mil laut. Kedua pesawat tempur TNI AU kembali mendekat untuk melakukan identifikasi. Begitu berhadapan, lagi-lagi Hornet langsung melancarkan aksi jamming dengan sikap bermusuhan, ditambah lagi mereka juga sudah mengunci pesawat F-16 dengan rudal Sidewinder. Perang elektronika atau electronic warefare berlangsung selama tiga menit, padahal penerbang TNI AU mencoba berkomunikasi namun Hornet AS terus berupaya mengubah frekuensi radio mereka.
Keempat penerbang tempur F-16 TNI-AU tetap berusaha mengetahui siapa yang melintasi perbatasan Indonesia. Ternyata, kelima pesawat yang terdeteksi sebelumnya berasal dari Kapal Induk USS Carl Vinson (CVN-70), yakni super-carrier kelas Nimitz yang sedang berlayar dari arah barat ke timur bersama dua fregat dan sebuah kapal perusak Angkatan Laut AS. Kapal induk ini mengangkut 100 pesawat tempur, 16 pesawat pengintai, dan enam helikopter, diawaki oleh 3.184 kelasi dan perwira, 2.800 pilot, serta 70 personel lainnya.

Dari hasil pantauan TNI AU, konvoi kapal perang AS yang berada di sekitar Pulau Bawean ini berkecepatan 20 knot dan tengah menuju Pulau Madura dan Kangean 12 jam kemudian. Guna keperluan diplomatik, TNI AU kembali mengirimkan pesawat lainnya untuk memantau pergerakan mereka, yakni pesawat intai Boeing 737 Surveiller. Dari hasil pengamatan udara pada pukul tujuh pagi pesawat pengintai menjumpai iringan kapal induk, sebuah kapal perusak dan dua kapal fregat menuju ke Selat Lombok. Jawaban yang diperoleh tetap sama, armada kapal perang AS tersebut tetap beranggapan bahwa mereka berada di perairan internasional. Pada kesempatan itu, mereka tetap memfoto kapal induk USS Carl Vinson, kedua fregat, dan kapal perusak AS. Pengintaian ini dikawal ketat oleh dua F/A 18 Hornet AL AS. Dari foto-foto tersebut, pemerintah akhirnya melancarkan protes ke AS karena memasuki perairan Indonesia tanpa izin. Dari analisa TNI AU, kapal-kapal itu datang dari utara lalu belok masuk ke ALKI-1 dan melaksanakan pelatihan tempur selama beberapa jam di barat laut Pulau Bawean. 


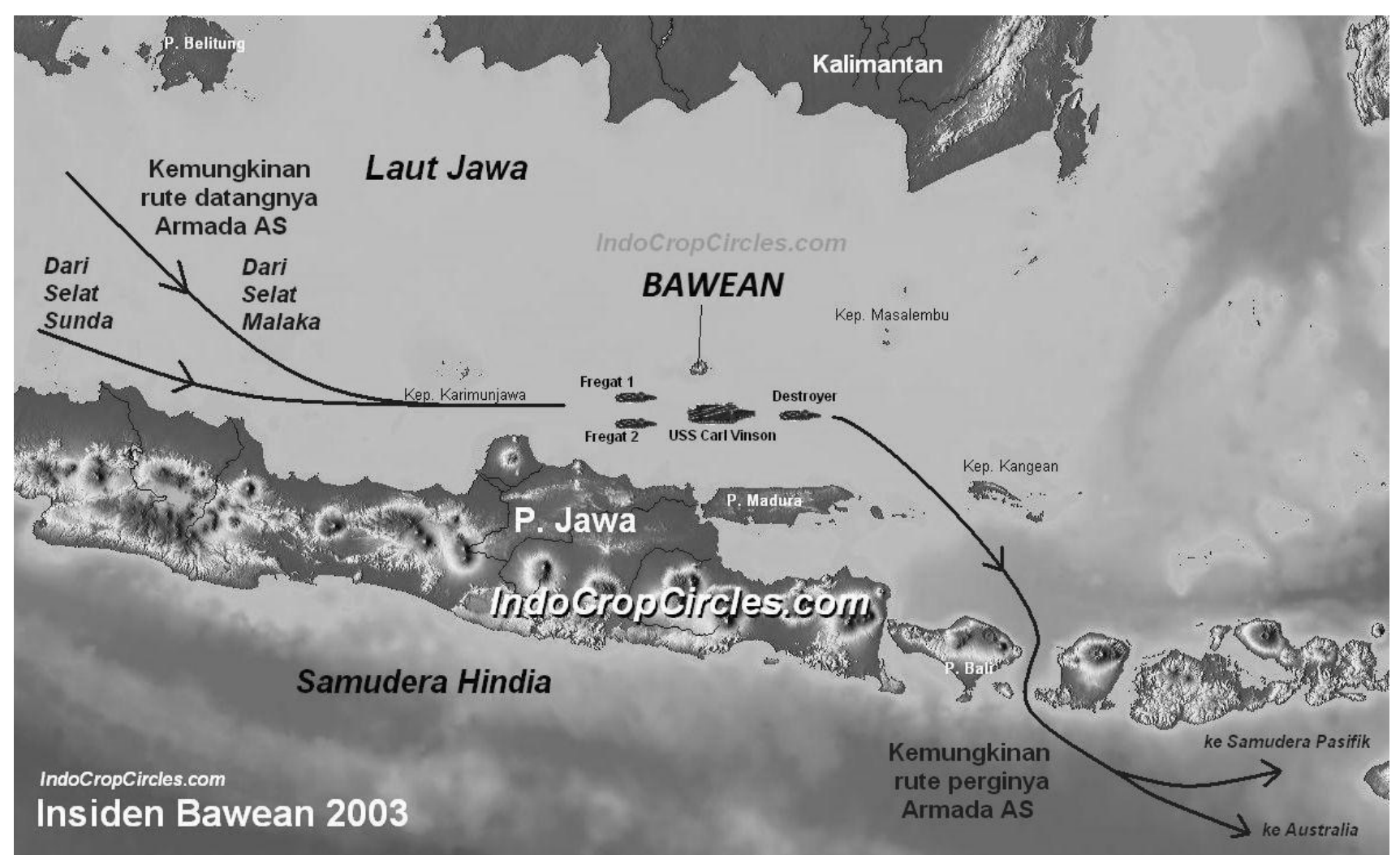

Gambar 2. Peta Insiden Bawean Tahun 2003

\section{Pengaturan terkait Lintas Alur Laut Kepulauan}

Indonesia telah menetapkan lintas alur laut kepulauan. Penentuan ini telah diatur lebih lanjut dalam peraturan perundang undangan Indonesia antara lain Undang Undang Nomor 6 Tahun 1996 tentang Perairan Indonesia, Undang Undang Nomor 17 Tahun 2008 tentang Pelayaran, Peraturan Pemerintah Nomor 37 Tahun 2002 tentang Hak dan Kewajiban Kapal dan Pesawat Udara Asing dalam melaksanakan hak lintas alur laut kepulauan melalui rute yang telah ditetapkan, Peraturan Pemerintah Nomor 5 Tahun 2010 tentang Kenavigasian dan Juklak Panglima TNI tentang Pengamanan Alur Laut Kepulauan Indonesia. ${ }^{21}$
Dalam Undang-Undang Nomor 6 Tahun 1996 tentang Perairan Indonesia dan Peraturan Pemerintah Nomor 37 Tahun 2002 tentang Hak dan Kewajiban Kapal dan Pesawat Udara Asing tidak mencantumkan secara jelas apa hak dan kewajiban Indonesia terkait dengan alur laut kepulauan. Peraturan perundangundangan ini hanya menyatakan bahwa garis sumbu dan titik penghubung dari alur laut kepulauan digambarkan/dicantumkan di peta laut atau tabel tentang daftar koordinat geografis garis sumbu.

Pasal 18 dan 19 Undang Undang Nomor 6 Tahun 1996 mengatur tentang hak lintas laut alur laut kepulauan di Perairan Indonesia. Pasal 18 menyatakan bahwa alur laut kepulauan merupakan pelaksanaan hak pelayaran dan penerbangan dengan cara normal untuk lintas yang terus menerus,

21 Kresno Buntoro, Op.cit, hlm 126-142. 
langsung dan tidak terhalang. Semua kapal dan pesawat udara menikmati hak lintas alur laut kepulauan di Perairan Indonesia, lintas antara satu bagian laut bebas atau ZEE ke bagian lain dari laut bebas atau ZEE. Pasal 19 secara khusus mengatur bahwa Indonesia menetapkan alur laut untuk pelaksanaan hak lintas alur laut kepulauan.

Di Indonesia terdapat empat jenis lintas sebagaimana diatur dalam Undang-Undang Nomor 6 Tahun 1996, akan tetapi dalam Undang-Undang Nomor 17 Tahun 2008 tentang Pelayaran hanya lintas alur laut kepulauan yang diatur. Tidak ada penjelasan resmi kenapa dalam undang-undang ini hanya mengatur alur laut kepulauan, semestinya dalam undang-undang ini mengatur keseluruhan lintas dimaksud. Dalam Pasal 194 Undang-Undang Nomor 17 Tahun 2008 tentang Hak dan Kewajiban Kapal dan Pesawat Udara Asing disebutkan, Pemerintah Indonesia menetapkan alur laut kepulauan Indonesia dan tata cara penggunaan alur laut kepulauan itu untuk perlintasan yang terus menerus, langsung dan secepatnya melalui perairan Indonesia.Peraturan Pemerintah Nomor 37 Tahun 2002 menyatakan bahwa kapal dan pesawat udara asing dapat melaksanakan hak lintas alur laut kepulauan melalui bagian tertentu alur teritorial dan perairan kepulauan Indonesia. Hak lintas alur laut kepulauan harus dilaksanakan melalui alur laut kepulauan khusus dan rute udara yang telah ditentukan.

Pada pengaturannya ALKI terdiri dari tiga, dari utara ke selatan, yaltu ALKI I, ALKI II dan ALKI III, yang di bagian selatan bercabang tiga menjadl ALKI III A, III B dan III C. Adapun ALKI I meliputi jalur lintas perairan Laut Jawa, Selat Sunda, Selat Karimata, Laut Natuna, dan
Laut Cina Selatan, yang menghubungkan lalulintas maritim dan perdagangan internasional dari Afrika, Australia Barat ke Laut Tiongkok Selatan, Jepang, dan sebaliknya. ALKI II meliputi jalur lintas perairan Laut Sulawesi, Selat Makassar, Selat Lombok, dan Laut Flores, yang menghubungkan lalu-lintas pelayaran dan perdagangan internasional dari Afrika ke Asia Tenggara dan Jepang, serta dari Australia ke Singapura, Tiongkok, dan Jepang, atau sebaliknya.

Sedangkan ALKI III A meliputi jalur lintas perairan Samudera Pasifik, Laut Maluku, Laut Seram (Bagian Timur Pulau Mongole), Laut Banda (bagian Barat Pulau Buru), Selat Ombai, dan Laut Sawu, yang menghubungkan jalur pelayaran dan perdagangan internasional dari Australia bagian Barat ke Filipina dan Jepang, atau sebaliknya. ALKI III B adalah jalur lintas perairan yang menghubungkan jalur maritim dan perdagangan internasional dari Laut Maluku, Laut Seram, Laut banda, dan Laut Arafuru, lalu selanjutnya ke Laut Banda, terus ke utara ke ALKI III A (Laut Seram, Laut Maluku, dan seterusnya), atau sebaliknya. ALKI III C menghubungkan jalur pelayaran dan perdagangan internasional dari Australia bagian Timur, Selandia Baru, dan Samudera Pasifik melalui Selat Torres, atau sebaliknya melalui Selat Torres, Laut Arafuru, Laut Banda, dan Laut Maluku. Secara realistis, ia menghubungkan dua perairan bebas, yakni Samudera Hindia dan Samudera Pasifik.

\section{Kedaulatan Wilayah Udara di ALKI pasca Pengesahan PP No .4 Tahun 2018 tentang Pamwilud}

Salah satu aspek yang perlu diperhatikan dalam pemanfaatan ruang udara beserta sumber daya alam di dalamnya adalah 
masalah yurisdiksi. Prinsip-prinsip dalam yurisdiksi adalah prinsip teritorial, nasional, personalitas pasif, perlindungan atau keamanan, universalitas dan kejahatan menurut kriteria hukum yang berlaku. ${ }^{22}$

Terkait dengan aspek yuridis, sebagai konsekuensi dari pengesahan UNCLOS, Indonesia wajib menyediakan Alur Laut bagi kapal-kapal (Sea Lane) dan pesawat-pesawat udara (Air Route) asing untuk melintasi teritori Indonesia. Alur itu, kemudian dikenal dengan ALKI yang muncul pada persidangan Organisasi Maritim Internasional pada tanggal 19 Mei 1998.

Sementara itu ruang udara suatu negara diatur dalam Konvensi Chicago 1944 yang menyatakan ruang udara suatu negara adalah complete and exclusive. Kedaulatan udara suatu negara merupakan kolom udara daratan suatu negara dan kolom udara di atas "territorial waters". Konvensi Chicago tidak menyinggung perairan kepulauan maupun ruang udara di atasnya. Konvensi Chicago mengatur penerbangan sipil, yang menyatakan bahwa rute udara diatur oleh ICAO. Sebaliknya UNCLOS 1982 mengatur ruang udara di atas daratan, perairan pedalaman, perairan kepulauan, dan laut teritorial suatu negara sebagai wilayah kedaulatan negara pantai/ kepulauan. Terkait dengan persinggungan tersebut muncul persoalan yaitu pelaksanaan hak lintas alur laut kepulauan oleh pesawat udara.

Pasal 53 ayat (2) UNCLOS 1982 menyatakan kapal laut dan pesawat udara menikmati hak lintas laut kepulauan dalam alur laut. Pasal 18 ayat (2) mengatur kapal laut dan pesawat udara asing memiliki hak lintas alur laut kepulauan melalui perairan kepulauan
Indonesia. Dalam prakteknya, pesawat udara (militer maupun sipil yang berada di atas kapal) yang akan terbang di ruang udara Indonesia harus memiliki ijin. Ini sesuai dengan Pasal 3 Konvensi Chicago 1944, pesawat udara asing jika akan melintas di ruang udara negara lain harus mendapat izin terlebih dahulu. Dengan demikian diasumsikan pesawat udara tidak dapat menikmati hak lintas alur laut kepulauan Indonesia.

Sebagai dasar mengenai kedaulatan wilayah udara Indonesia disebutkan dalam Pasal 1 UU No. 1 Tahun 2009 tentang Penerbangan bahwa wilayah udara Indonesia sebagai wilayah kedaulatan udara di atas wilayah daratan dan perairan Indonesia.

Pengakuan terhadap kedaulatan wilayah udara Republik Indonesia, dalam Pasal 5 UU Nomor 1 Tahun 2009 tentang Penerbangan menyatakan bahwa Negara Kesatuan Republik Indonesia berdaulat penuh dan eksklusif atas Wilayah Udara Republik Indonesia. Dalam melaksanakan ketentuan dalam UndangUndang tentang penerbangan tersebut maka pada PP No. 4 Tahun 2018 tentang Pamwilud juga mencantumkan tentang kedaulatan wilayah udara tersebut dalam Pasal 3.

PP No. 4 Tahun 2018 tentang Pamwilud secara lebih spesifik memberikan definisi mengenai tata cara dan prosedur pemaksaan mendarat terhadap pesawat udara asing tidak berizin di wilayah udara Indonesia. Hal ini tercantum dalam Pasal 10 yang menyatakan bahwa pesawat udara sipil asing tidak berjadwal yang terbang harus memiliki izin diplomatik (diplomatic clearance), izin keamanan (security clearance), dan persetujuan terbang (flight approval). 
Pelanggaran wilayah udara, yaitu penerbangan memasuki wilayah negara lain tanpa izin bisa bersifat sengaja misalnya untuk kegiatan mata-mata atau penerbangan gelap. Tindakan pelanggaran wilayah udara Indonesia yang dilakukan oleh pesawat udara sipil asing diancam ketentuan pidana berdasarkan Pasal 414 Undang-Undang Nomor 1 Tahun 2009 tentang Penerbangan. Sedangkan penerbangan gelap yang tidak sengaja bisa karena tersesat akibat cuaca atau kondisi alam lainnya atau pesawat mengalami keadaan darurat.

Negara yang dilanggar wilayahnya mempunyai hak untuk mengambil tindakan intersepsi atas pelanggaran tersebut. Tindakan intersepsi bisa bersifat ringan sampai tindakan yang bersifat berat, tergantung dari tingkatan bentuk-bentuk ancaman yang dihadapi. Tindakan peringatan ringan misalnya dilakukan dengan cara memberitahukan pesawat udara tersebut untuk keluar dari wilayah udara Indonesia. Sedangkan tindakan intersepsi yang berat adalah tindakan pemaksaan mendarat (force down) terhadap pesawat udara yang melakukan pelanggaran wilayah udara. Apabila dalam hal pelanggar adalah pesawat udara militer maka dapat dilakukan penembakan apabila mereka menolak instruksi pendaratan oleh negara yang dilanggar. Pesawat udara sipil atau militer dapat dipaksa mendarat apabila pesawat tersebut memasuki wilayah udara nasional secara tidak sah, namun dapat dipastikan bahwa pesawat udara yang bersangkutan tidak akan mengancam keselamatan objekobjek vital yang berada di bawahnya.

Penegakan hukum terhadap pelanggaran wilayah udara diatur pada Pasal 8 UndangUndang Nomor 1 Tahun 2009 tentang
Penerbangan dan Pasal 31 hingga Pasal 36 PP No. 4 Tahun 2018 tentang Pamwilud. Pesawat udara yang melanggar wilayah udara kedaulatan Indonesia diberikan peringatan serta diberi perintah tegas untukmeninggalkan wilayah udara Indonesia oleh petugas pemandu lalu lintas penerbangan (Air Traffic Controller/ATC). Petugas pemandu lalu-lintas penerbangan wajib memberikan seluruh data serta informasi terkait pelanggaran wilayah udara kepada aparat penegak hukum yang mempunyai tanggung jawab secara khusus pada masalah pertahanan negara.

Kemudian jika peringatan tidak diindahkan maka dilakukan tindakan intersepsi hingga tindakan pemaksaan mendarat oleh pesawat tempur negara kolong yang bersangkutan (dalam hal ini TNI AU) untuk mendarat di pangkalan udara atau bandara tertentu yang berada di wilayah Indonesia. Selanjutnya awak personel yang ada di dalam pesawat udara, kemudian pesawat udara itu sendiri, serta seluruh muatannya yang diindikasikan melanggar ketentuan diperiksa dan disidik sesuai dengan ketentuan perundangundangan yang berlaku.

Pada fase itu pihak TNI AU menjadi pihak yang mempunyai wewenang melakukan penegakan hukum terhadap pesawat udara serta awak pesawat yang melanggar wilayah udara Indonesia. Berdasarkan pada Pasal 10 Undang-Undang Nomor 34 Tahun 2004 tentang TNI disebutkan bahwa Angkatan Udara mempunyai tugas untuk melaksanakan tugas TNI matra udara di bidang pertahanan; menegakkan hukum dan menjaga keamanan di wilayah udara Indonesia sesuai dengan ketentuan hukum nasional dan hukum internasional yang telah diratifikasi; melaksanakan tugas TNI dalam pembangunan 
dan pengembangan kekuatan matra udara; serta melaksanakan pemberdayaan wilayah pertahanan udara. Dalam penjelasan Pasal 10 tersebut menyatakan bahwa yang dimaksud dengan menegakkan hukum dan menjaga keamanan udara adalah segala usaha, pekerjaan dan kegiatan untuk menjamin terciptanya kondisi wilayah udara yang aman serta bebas dari ancaman kekerasan, ancaman navigasi, serta pelanggaran hukum di wilayah udara yurisdiksi Indonesia. ${ }^{23}$

Di dalam UNCLOS sendiri memang tidak mengatur semua isu kelautan, selain itu ada juga pengaturan yang kurang jelas dan cenderung kabur. Pengaturan dalam UNCLOS cenderung tidak rigid dan jelas disebabkan adanya akomodasi kepentingan dari banyak negara. Aktivitas militer juga tidak diatur dalam Konvensi tersebut, sehingga menyebabkan terjadinya beberapa insiden terkait implementasi dan interpretasi ketentuan Konvensi. Sebagai contoh adalah insiden Bawean tahun 2003 dan lalu lintas kapal dan pesawat udara asing di Laut Natuna. Untuk itu ada korelasi yang erat antara aspek operasional dan legal terkait dengan mekanisme penanganan kapal dan pesawat udara asing yang melintas di perairan Indonesia. ${ }^{24}$

PP No.4 Tahun 2018 tentang Pamwilud ini menegaskan kedaulatan Indonesia khususnya di ruang udara di atas ALKI. Dalam berbagai peraturan lainnya Indonesia telah menetapkan alur laut kepulauan dan memformulasikan hak dan kewajiban yang boleh maupun tidak boleh dilakukan oleh kapal dan pesawat udara ketika melaksanakan hak lintas alur laut kepulauan. Dalam Peraturan Pemerintah ini diatur lebih spesifik mengenai delik maupun unsur-unsur pelanggaran termasuk sanksi yang dapat disangkakan serta siapa atau pihak yang mempunyai kewenangan melaksanakan penegakan hukum tersebut.

Dalam PP ini pengaturan mengenai pesawat udara asing yang melalui ALKI diatur dalam Pasal 19 hingga Pasal 23. Beberapa pengaturan penting diantaranya mengenai Pesawat Udara Negara Asing dapat melaksanakan hak lintas udara di atas Alur Laut Kepulauan dan/atau transit pada alur yang telah ditetapkan untuk penerbangan dari satu Bandar Udara atau pangkalan udara negara asing ke Bandar Udara atau pangkalan udara negara asing lainnya melewati laut lepas atau Zona Ekonomi Eksklusif tanpa mengganggu kepentingan Indonesia di Wilayah Udara Yurisdiksi.

Selain itu diatur pula bahwa Pesawat Udara Negara Asing yang terbang di atas Alur Laut Kepulauan harus mematuhi ketentuan penerbangan yang berlaku di Indonesia dan ketentuan penerbangan yang ditetapkan oleh Organisasi Penerbangan Sipil Internasional untuk kepentingan Keselamatan Penerbangan. Selain itu Pesawat Udara Negara Asing yang melintas di luar Alur Laut Kepulauan harus memiliki Izin Diplomatik (diplomatic clearance) dan Izin Keamanan (security clearance).

Pesawat Udara Negara Asing dan Pesawat Udara Sipil Asing yang terbang melewati rute udara di atas Alur Laut Kepulauan tidak sesuai dengan ketentuan merupakan pelanggaran. Terhadap Tindakan pelanggaran ini dilakukan tindakan pengenalan secara visual, pembayangan, penghalauan, dan/atau

\section{T. Bambang Widarto, Op.cit, hlm. 86-91.}

24 Kresno Buntoro, Op.cit., hlm viii. 
pemaksaan mendarat oleh Pesawat Udara TNI.

Penegakan hukum disini merupakan salah satu upaya untuk mempertahankan kedaulatan negara. Sebagai negara yang berdaulat, Indonesia perlu menerapkan seperangkat aturan hukum untuk mengatur, mengendalikan, dan menegakkan hukum udara di ruang udara di atas ALKI dengan berpedoman pada kepentingan bangsa dan negara Indonesia serta memperhatikan kaidah-kaidah yang diatur dalam hukum internasional.

\section{Penutup}

Dalam penelitian ini dapat disimpulkan bahwa pemberlakuan 3 (tiga) jalur ALKI di lautan teritorial Indonesia untuk mematuhi UNCLOS 1982 sebagai konsekuensi diterimanya Wawasan Nusantara (archipelagic state), menyebabkan wilayah Indonesia rawan akan ancaman kepada kedaulatan wilayah. Indonesia melalui peraturan perundang-undangannya telah menetapkan alur laut kepulauan dan memformulasikan hak dan kewajiban yang boleh maupun tidak boleh dilakukan oleh pesawat udara ketika melaksanakan hak lintas alur laut kepulauan. Dalam PP No.4 Tahun 2018 tentang Pamwilud secara khusus telah mengatur mengenai delik ataupun unsur-unsur pelanggaran termasuk sanksi serta siapa yang mempunyai kewenangan untuk melaksanakan penegakan hukum jika terjadi pelanggaran oleh pesawat udara tidak berizin di ruang udara di atas ALKI.

Sebagai saran untuk mendukung pengamanan di ruang udara di atas ALKI terhadap berbagai tindakan pelanggaran wilayah udara perlu diberikan payung hukum secara komprehensif untuk mendukungnya.
Hal ini dapat dilakukan dengan menetapkan Zona Identifikasi Pertahanan Udara (ADIZ) bagi keperluan identifikasi pesawat udara untuk kepentingan pertahanan dan keamanan negara. Penetapan ADIZ ini dapat dilakukan melalui Keputusan Presiden (Keppres) dengan Kementerian Pertahanan sebagai leading sector pembahasannya.

Selain itu perlu segera dilaksanakan pembahasan peraturan turunan PP No.4 Tahun 2018 tentang Pamwilud khususnya Peraturan Menteri Perhubungan yang mengatur detail mengenai besaran perhitungan denda administratif bagi pelaku pelanggaran wilayah udara Indonesia. Kedepannya untuk mencegah terjadinya lagi pelanggaran wilayah udara maka diperlukan penataan regulasi yang jelas, efektif, dan harmonis; penegakan hukum yang tegas dan konsisten; koordinasi yang kuat, termasuk civil-military coordination.

\section{Daftar Pustaka}

\section{Buku}

Abdurrasyid, Priyatna, Kedaulatan Negara di Ruang Udara (Jakarta: Fikahati Aneska, 2003

Buntoro, Kresno, Alur Laut Kepulauan Indonesia (ALKI). Prospek dan Kendala. (Jakarta: Seskoal, 2012)

Buntoro, Kresno, Lintas Navigasi di Nusantara Indonesia (Jakarta: Rajawali Press, 2014)

Hakim, Chappy, Quo Vadis Kedaulatan Udara Indonesia (Jakarta: Red \& White Publishing, 2012)

Kansil, C.S.T. dan Christine S.T. Kansil, Hukum Tata Negara Republik Indonesia (Jakarta: PT Rineka Cipta, 2000)

Kusumaatmadja, Mochtar, Konsepsi (Negara) Kepulauan Dalam Hukum Laut dan Wawasan Nusantara (Jakarta: Badan Pembinaan Hukum Nasional)

Soekanto, Soerjono dan Sri Mamudji, Penelitian Hukum Normatif. Suatu Tinjauan Singkat, (Jakarta: Raja Grafindo Persada, 2004) 
S.K., Wahyono, Indonesia Negara Maritim, (Jakarta: Teraju, 2009),

Widarto, T. Bambang, Tinjauan Hukum Udara Sebagai Pengantar. Dalam Perspektif Hukum Internasional dan Nasional, (Jakarta: Sekolah Tinggi Hukum Militer, 2015),

Yani, Yanyan Mochammad, Ian Montratama dan Ikradhi Putera. Langit Indonesia Milik Siapa? Makna Strategis Wilayah Pengendalian Udara (FIR) Indonesia-Singapura, (Jakarta: Elex Media Komputindo, 2017)

United Nations Convention on The Law of The Sea (UNCLOS) 1982, dicetak dan disebarluaskan oleh Dewan Kelautan Indonesia, 2009

\section{Makalah/Artikel/Prosiding/Laporan/Hasil Penelitian}

Almond, Roncevert. Clearing the Air Above the East China Sea: The Primary Elements of Aircraft Defense Identification Zones. Harvard National Security Journal, Vol.7 Tahun 2016, 126-196
Bakhtiar, Handar Subhandi, Syamsuddin Muhammad Noor dan Abdul Maasba Magassing. Violation of The Sovereignty Of Indonesia Airspace By Foreign Aircraft. International Journal of Advanced Research (IJAR), Februari 2017, hlm. 2107-2113

Risdiarto, Danang, "Analisis Pemaksaan Mendarat (Force Down) Terhadap Pesawat Udara Asing Tidak Berizin Di Wilayah Udara Indonesia," Sekolah Kajian Stratejik dan Global Universitas Indonesia, Jakarta, 2018

Risdiarto, Danang, "Penegakan Hukum Terhadap Pelanggaran Wilayah Udara Yurisdiksi Indonesia Oleh Pesawat Terbang Asing Tidak Terjadwal," Jurnal Rechtsvinding Vol.5 No.1 Tahun 2016: 69-82

Rustam, Imah, "Tantangan ALKI dalam Mewujudkan Cita-cita Indonesia sebagai Poros Maritim Dunia," Indonesian Perspective Vol 1 No. 1 (Januari-Juni): 1-21

Soegiyono, "Kajian Kedaulatan Negara Di Ruang UdaraTerhadap Alur Laut Kepulauan Indonesia (ALKI)," Berita Dirgantara Vol.12 No.2 Juni 2011: 76-82 